\section{Верка Карић}

verka_karic@yahoo.com

Универзитет у Крагујевцу

Филолошко-уметнички факултет https://doi.org/10.18485/knjiz.2021.11.11.10

УДК: 821.134(82).09-31 Валенсуела Л.

Оригинални научни чланак

\title{
Идентитетска потрага жене у роману Мораш да се смешкаш Луисе \\ Валенсуеле
}

Рад се бави романом Мораш да се смешкаш (Нау que sonreír) ауторке Луисе Валенсуеле (Luisa Valenzuela), у покушају да осветли рађање феминистичких идеја у ауторкином, али и аргентинском књижевном стваралаштву. У роману се кроз протагонисткињу Клару критички тематизује положај жене и њена идентитетска потрага. У раду је наглашен утицај друштва и породице при формирању женског идентитета и положаја. Такође, анализира се на који начин ауторка представља тело протагонисткиње као поприште старих и нових идеологија у Аргентини шездесетих година XX века. Породица и друштво створиће систем у оквиру којег се жена налази потчињена мушкарцу и његовим одлукама. Из тога произлази објективизација и дехуманизација протагонисткиње кроз коју Валенсуела представља читаву генерацију потчињених и ућутканих жена.

Кључне речи: идентитет, жена, феминизам, Луиса Валенсуела

Пишем против оних који сматрају да имају све одговоре. Надам се да ће свака од мојих књига бити расадник питања који рађа још нових питана и на срећу не даје готово ниједан одговор. (Valensuela 2019: 114)

Кроз историју хиспаноамеричке књижевности женски ликови су се традиционално категорисали као добри или лоши у зависности од тога да ли су испуњавали друштвена очекивања. Жене су биле подложне дефинисању с мушког становишта, што као последицу има ограничавање њиховог развоја. Уобичајена идеализација жене и услед тога додељивање улога као што су домаћица, верна жена и вољена мајка, довела је до стварања патријархалног модела у друштву. Мајке и верне супруге представљале су добре жене према критеријумима патријархалног друштва, док су се лошим женама сматрале оне које су излазиле из тих оквира (Pina 2006: 297). Почетком XX века у многим земљама Хиспанске Америке јављају се феминистички покрети како би се спровеле политичке и друштвене промене по питању права жена. Промене су се односиле пре свега на права жена када је у питању њихова улога и место 
у домаћинству и друштву (Rohrer 2012: 7-8). Процес глобализације и борбе феминисткиња доводи до стварања другачије књижевности у којој је акценат на борби за права жена. Новом правцу књижевности припадају и дела Луисе Валенсуеле (Рina 2006: 297).

Слобода у друштву, либерална размишљања, као и права која се тичу равноправности полова уско су повезани с политичком ситуацијом у држави. Политичка нестабилност, нагле промене на власти и дисконтинуитет борби за демократију могу значајно да утичу на социо-културолошки напредак (Prigorian 2017: 87). У оваквим друштвеним и културолошким околностима јављају се различити видови неравноправности које су производ друштва чија је структура заснована на родној неједнакости (Sagot 2008: 215).

Роман Мораш да се смешкаш значајан је при анализирању теме женског идентитета као и фактора који утичу на његово формирање. Дело Луисе Валенсуеле настаје уочи ширења феминистичких покрета у Аргентини, а обрађује тему патријархалног положаја жене и опхођења према њој. Стога, циљ рада је анализа начина на који се у роману приказује борба за нов идентитет и положај жене. Такође, анализа романа даје нам увиде у почетке феминистичких идеја ауторке романа.

\section{Друштвене околности Аргентине и рађање феминистичких идеја}

Дела Луисе Валенсуеле карактерише друштвени набој, те је потребно осврнути се на друштвени оквир Аргентине крајем шездесетих и почетком седамдесетих година $\mathrm{XX}$ века, када настаје њен роман. Предочавањем друштвених околности разумеће се са̂м контекст романа, као и питања која се у њему јављају, а повезана су с борбом за нови идентитет.

Почетак XX века био је буран за земље Хиспанске Америке јер је то период који је обележен кризама на различитим пољима. Политичке, економске и друштвене кризе нису заобишле ни Аргентину и имале су снажан утицај на друштво. Овај период обележен је репресијом и диктатурама које су се смењивале једна за другом. Једна од последица насиља током периода диктатура је социјални сукоб унутар државе који је био најприсутнији код оних који су били незапослени или одбачени од друштва (Romero 2007: 130). Паралелно с тим, шездесетих година XX века радикализовале су се две идеологије које су се поклопиле са сукобима почетком седамдесетих година XX века. С једне стране, развијала се либерална и прогресивна идеологија, док је на другој 
страни била антилиберална, чија је основа католичка конзервативна идеологија (Romero 2007: 24). У овом периоду почиње слободније да се говори о сексуалности, прихваћене су ванбрачне заједнице, што је довело до ублажавања предрасуда, и осуда двоструког морала по питању рода. У Аргентини су се успостављале норме између старих и нових ставова о друштвеним улогама и моделима. Стари модел домаћинства и положаја подразумевао је жену чији је задатак био да обавља кућне послове и чува децу, док би мушкарац био задужен за издржавање породице. Насупрот томе, нови ставови покрећу питања развода, укључивање жена на тржиште рада и рађање ван брака (Cosse 2006: 40-41). Дотадашњи ставови подразумевали су да је углед младих жена био повезан с њиховим сексуалним животом, односно невиношћу, а идентитет се заснивао на њиховом статусу кћерки, супруга и мајки. С друге стране, мужевност је била повезана са сексуалним развојем и експериментисањем, док је зрелост мушкарца повезивана с постизањем радног положаја и способности да изграде и економски издржавају породицу. Говорећи о процесу модернизације сматрало се да су породични и брачни односи средиште промена које су утицале на економију, културу и вредности друштва које прелази из традиционалног у модерно (Cosse 2006: 41). Стога, млади су покренули протесте услед тежње да се промени и обнови наслеђени менталитет (Favero 2016: 225).

Током периода диктатура у Аргентини јавља се проблем насиља које је постало свакодневно и прихваћено. Када је реч о насиљу над женама, мучење није служило само као казна када је реч о политичким преступима, већ и када је реч о друштвеним правилима женског понашања. Са̂м чин насиља, који је најчешће био сексуалног карактера, имао је за циљ да жене учини пасивним, крхким и послушним (Marković 2013: 207). Други вид сексуалног насиља над женама била је проституција, па се поставило питање да ли је проституција насиље над женама и ропство, или се може сматрати послом. У вези с тим се развијају две стране, једна која има за циљ легализовање проституције као посла, и друга која има за циљ да се оно укине јер се сматра врстом родног насиља (Morcillo 2017: 215). Нове околности утичу и на посматрање самог сексуалног чина, који се из традиционалног угла дефинише као опасност, док се из либералне перспективе представља као начин за истраживање и уживање (Morcillo 2017: 225). Сексуално насиље над женама кроз историју показало је, међутим, да се сексуалност жена посматрала као нешто што треба бити контролисано и да је сврха женске сексуалности репродуктивност (Justovon Lurzer 2013: 91). У оваквим 
друштвеним и политичким околностима настаје први роман Луисе Валенсуеле, Мораш да се смешкаш.

\section{Писати телом}

Луиса Валенсуела користи тему сексуалности као почетно место женске потчињености и репресије, а тело жене представља као главну тачку која се напада. При томе се мисли на објективизацију и дехуманизацију жене од стране друштва. На тај начин женско тело постаје средство борбе против патријархалног система. Свака жена другачије реагује на нападе, а кључ у борби против потчињености је у томе да се нађе савршено оружје. Проналазак савршеног оружја подразумева проналажење начина да се изразе властити ставови жена и њиховог начина да се одупру ауторитативном режиму. Валенсуелино оружје у тој борби јесте моћ нарације, односно могућност њених јунакиња да саме испричају своју причу (Hatry 2010: 243).

Оно што карактерише феминистичко писање Луисе Валенсуеле јесте концепт писања телом (escribir con el cuerpo). ${ }^{1}$ Овај концепт се заснива на промишљању о уживању као таквом, жељама и језику који је карактеристичан за жене. Њена промишљања су социолошког, политичког и психоаналитичког карактера (Marković 2013: 89). Валенсуела посматра тело као једино место са којег може да се приступи женском искуству (Magnarelli 1996: 58). Кроз тело и на телу видимо однос моћи при чему се не мисли само на мушкарца који жели да потчини жену, већ и на друштво које је маргинализује. Осим тога, истраживањем сексуалности жене испитују идентитет који им је наметнут уједно рушећи његове границе. Валенсуела објашњава овај концепт као заједничко деловање главе и оног другог односно нагона који нас терају да се крећемо, плешемо и дишемо. Немогућност комуницирања уз помоћ речи има као последицу комуницирање преко тела (Hatry 2010: 339). Телом пишу потлачени, они којима је глас одузет, они чија стварност не може бити артикулисана доминантним дискурсима моћи и самим тим тело постаје оруђе побуне. Ожиљци, повреде, опекотине као и насиље које се врши над њиховим телима али и њихово еротизовање указују на женски положај у друштву и преносе њихово искуство чак и када оне бивају ућуткане. Валенсуелина техника писања телом повезана је директно с искуством живота у диктатури (Marković 2013: 189-190). Писање ауторке има као крајњи циљ слободу, при чему се мисли на сексуалну, политичку и културолошку слободу жена (Hatry 2010: 344). 
Роман Мораш да се смешкаш прво је дело ове ауторке, објављено 1966. године. Структура дела је таква да је подељено на три целине, прва је Тело, затим Међустање, и на крају трећа целина под називом Глава. Тематика романа је и даље актуелна и заступљена у Аргентини, због чега је роман предмет истраживања и деценијама након првог објављивања. Роман је писала док је боравила у Паризу, а удаљеност јој је дала бољу перспективу у сагледавању проблема женског питања. ${ }^{2}$ Назив романа је ироничан и алудира на позицију жене која мора да буде послушна и захвална патријархалном друштву чак и у ситуацијама у којима пати. Доналд Шо (Dondal Shaw) сматра да је ово дело протофеминистичко (Marković 2013: 23).

\section{Утицај породице и друштва у идентитетском проналажењу}

Дела Луисе Валенсуеле баве се динамичним односом тела, језика и политичких околности. Оно што спаја ова три аспекта јесте моћ, односно њено исказивање. Валенсуелино стваралаштво на различите начине приказује шта се дешава када жена изађе из улога наметнутих од стране друштва (Díaz 2001: 164). То је случај и у делу Мораш да се смешкаш, у којем Валенсуела приказује стеге друштва и како оне утичу на протагонисткињу Клару.

Представљајући идентитетско формирање протагонисткиње, ауторка полази од утицаја породице на појединца. Протагонисткиња долази у Буенос Аjpec, и услед неспоразума завршава у делу града у ком су проститутке. Проституција постаје и њена професија пошто ју је отац избацио из куће, на шта је она пасивно пристала (Valensuela 2017: 12). Недостатак борбености и сопственог гласа у оквиру породице доводи до тога да се Клара касније препушта вољи мушкараца и дозвољава да јој они контролишу живот. На самом почетку романа Клара упознаје Дон Марија који јој нуди своју заштиту и помоћ. Прихватањем његове понуде он преузима очинску фигуру:

Али ја нисам од оних који искоришћавају друге - уздахну. - А сем тога, данас је све постало тако ризично. Али ја те нећу никако повредити, видећеш и сама. Заштитићу те као отац.

Чему све служе очеви, Када би ти знао причу мога оца... (Valensuela 2017: 19) 
Када су у питању Клара и њена породица, о родитељима се не говори, осим када се наговештава да је мајка оставила њу и оца (Valensuela 2017: 12). Прећутно се ставља до знања да је Клара производ дисфункционалне породице и да бива принуђена да сама тражи пут кроз живот. Модел понашања који види у својој кући она ће пренети даље кроз живот, што представља критику породичних односа.

Иако се бавила проституцијом, Клара није имала потребу да пронађе другачији посао, већ је проналазила решење у томе да се уда. Управо кроз њене амбиције Валенсуела приказује положај жене у аргентинском друштву. Женин циљ у складу с нормама друштва морао је бити да тежи браку и мајчинству. Све што је било другачије од устаљеног шаблона био је лош пример. Кларина потреба да удовољи стандардима друштва види се у њеним размишљањима:

Када сам ја била мала, да будем добра је значило да помогнем мами да очисти под, опере судове, и такође да сваке недеље одем на мису. Касније је да будем добра значило да не пустим момке да ме љубе у мрачним улицама и да их опоменем када ме пипкају. Шта ли ког врага данас значи бити добар? (Valensuela 2017: 89)

Растрзаност Кларе која је кроз роман све јача представља сукоб идеологија присутних у Аргентини шездесетих година XX века.

Анализом Клариних односа с мушкарцима закључује се да она у њима види могућност да буде заштићена и збринута, уместо да тежи томе да буде самостална. Последица тога јесте да је у свим тим односима она губила своје ја, глас и право на своје жеље и ставове. Губитак Кларине личности био је постепен, а сваки мушкарац је одређивао своја правила. Ограничавање и контролисање жене у Валенсуелином роману је двоструко. С једне стране, мушкарци контролишу њено тело, посматрају је као објекат и дехуманизовано биће. С друге стране, Клари се намеће улога супруге и домаћице, при чему се приказује другачији вид дехуманизације. Стављање жене у друштвене калупе, одузимање њених основних права и слободе доводи до објективизације и дехуманизације женског тела и духа.

Патријархално друштво заузима став да је мушкарац тај који доноси одлуке, који говори, па је такав случај био и у Кларином браку: 
Тек су се били упознали и Клара је већ схватила да с њим није вредно труда отварати уста. Идеја да неће моћи да говори није је превише узнемирила јер нико јој неће забранити да настави тихи али силни унутарњи дијалог. (Valensuela 2017: 26)

Клара је много чистила не бунећи се никада зато што он није допуштао да му се одговара а она је већ била изгубила гласовне способности мада се вешто служила маштом. (Valensuela 2017: 27)

Ипак, у овим ситуацијама можемо видети унутрашњи отпор протагонисткиње, као и покушаје мушкарца да наметну своја уверења и ставове. Њена наметнута улога била је да води домаћинство и да преузме улогу супруге. Осим тога, њен муж Виктор решава у Кларино име да се она неће више бавити старим послом и забрањује јој да тражи било који посао ван куће. Кроз њихов однос се заправо осликава патријархално виђење да је мушкарац тај који зарађује, доноси одлуке док је жена она која води бригу о домаћинству. Клара, међутим, није била срећна у таквом односу и машта о мору, које заправо представља слободу коју није имала. Иако се више није бавила проституцијом њено тело и даље није било њено, и даље је припадало некоме ко је одлучивао уместо ње. Последица тога је предаја Кларе и прихватање да од сањарења о слободи нема ништа јер су њене могућности ограничене, да то о чему машта никада неће моћи да постигне: „Мушкарци не схватају да жена не може да досегне плафон, а камоли небо“ (Valensuela 2017: 67).

Међутим, њен унутрашњи отпор одразиће се кроз чин напуштања Виктора и даљом потрагом за својим идентитетом. Након тога, Клара упознаје Алехандра и од момента њиховог сусрета ауторка наглашава његову жељу да присвоји Клару. Пример тога је њихов први разговор у којем му она говори своје име и како жели да га промени јер су јој многи рекли да оно не иде уз њу. Када га је упитала које име се њему свиђа, рекао јој је да ће се звати Клара, али да то није исто име. Пре је била нечија друга Клара, сада се зна коме припада, односно биће његова Клара (Valensuela 2017: 102). На тај начин Алехандро третира Клару као предмет, што се види у тренутку када јој каже да ће она заувек остати с њим јер је он донео ту одлуку. Ипак, промена имена може се протумачити као Кларина потреба за идентификовањем, које у овом случају врши мушкарац. Алехандро и Клара ће ступити у брак, а Алехандрова одлука да се ожени 
Кларом није био гест љубави већ исказивање моћи (Rohrer 2012: 12), начин да је контролише да му не би побегла као што је побегла мушкарцима пре њега.

- Венчаћемо се, јеси ли чула? - поновио јој је како не би оставио места за сумњу.

Клара се још није сасвим разбудила и склапале су јој се очи.

- Али ја не знам да ли желим да се венчам... - приговорила је.

- Наравно да желиш, чему другом би ти могла да тежиш?

- Да тежим, ничему. Раније сам, истина, желела да се удам, али сада... не знам више. (Valensuela 2017: 133)

Разлог због којег Клара пристаје на брак није љубав колико заштита, јер је веровала да ће бити безбедна ако буде била нечија жена. Осим тога, кроз овај разговор види се заправо Кларино лутање и побуна. Она је желела да буде супруга и мајка пре свега јер је то значило бити добар за друштво. Та њена жеља се касније мења и она трага за собом и оним што ће је испунити, односно за слободом. Приликом њене потраге, Алехандро и Клара су почели да раде заједно, и мада се чини да долази до напретка, то је заправо само део Алехандровог плана да је контролише. Клара убрзо схвата да, иако живи достојанственије откад је у браку, и даље нема слободу и осећа се као звер у кавезу. На крају, она одустаје од борбе, свесна да је доживотни уговор који је потписала с Алехандром коначни губитак њене слободе:

Не могу више да трчим. Алехандро ће ме стићи и моја судбина ће бити да заувек живим затворена у хотелу, а унутар хотела у шатору, а унутар шатора у сандуку, а унутар свега тога ја, опкољена сандуцима и шаторима и хотелима, зато што сам ставила потпис. (Valensuela 2017: 178)

Управо у овом Кларином закључку ауторка упућује критику друштву и ставу да је брак крајњи циљ једне жене. Сам брак и достојанствен живот значио је затвор за Клару подједнако као и недостојанствен живот проститутке. Иако је поступала по друштвеним нормама, одрекла се своје слободе и свог гласа. Чак и сам назив романа упућује на то да је жена у обавези да се смешка и крије своје проблеме зарад мишљења јавности. Клари то постаје јасно када јој Алехандро каже више пута да мора да се смешка без обзира на то што је несрећна или што јој је тешко, чак ће то бити и њене 
последње речи пре него што је он убије. Насилна смрт Кларе, од стране мушкарца, симболично представља њихову моћ над женама. Протагонисткиња је живела у свету у којем су владали мушкарци, који су насилно контролисали жене, самим тим њена смрт симболично приказује како од тога није могла да побегне.

\section{Тело као средство говора}

Роман показује експлоатисање жене и њено потчињавање у друштву. Валенсуела је писала роман у периоду када су почели да се формирају феминистички покрети у Аргентини који су се борили против устаљених стереотипа о положају и улози жене.

Како би истакла критику таквог друштва, Луиса Валенсуела своју протагонисткињу описује као оличење вредности које су се приписивале жени тог периода. Клара је самим тим представљена као нежна, наивна, покорна и пасивна. Међутим, Валенсуела ће на Кларином примеру истаћи незадовољство, фрустрацију и унутрашњу борбу жене. Валенсуелина протагонисткиња се у животу препушта онима који су од ње тражили само тело и чезне да дочека тренутак када ће користи главу, односно када ће је неко видети као нешто више од дехуманизованог објекта. Касније, када добије прилику да изводи мађионичарски трик са својим мужем Алехандром, по први пут моћи ће да користи главу, а не тело:

[...] али не, никаква штета, то је благослов с неба зато што ћу коначно моћи да радим главом, само главом, без овог тела које ми само смета и доводи ме у невољу. Треба користити главу, како ми је говорила учитељица. Треба користити главу... ипак, нисам била лоша ученица, управо супротно, али нешто мора да ми је фалило сигурно. Одсад ћу моћи да користим главу и само главу. Нема зашто да се јадам. (Valensuela 2017: 155)

Иако се чини да долази до напретка, то је само привремено док Клара не схвати да се и њена глава дехуманизује исто као и тело. На исти начин на који је њено тело посматрано као објекат посматра се и њена глава, односно њена размишљања: она и даље нема слободу и све њене потребе и жеље се потискују. Клара схвата да то што се служи главом значи да мора да заборави на своје тело и да се одрекне својих жеља. Док је користила тело оно је припадало другима, а њене потребе су биле потиснуте, што је 
на крају био случај и када је користила главу. Она не користи своје тело како би се попела на вишу лествицу у друштву, већ је реч о преживљавању.

Простор у којем се гради овај лик посматран је на два начина. С једне стране, проститутке се посматрају као оне које доносе задовољство и као музе инспирације, док су, с друге стране, представљене као опасност, претња и грех. Изложене су околностима које представљају опасност за њих, а та опасност се односи на изложеност насиљу и понижавању. Принцип по ком се проститутке посматрају као објекти даје њиховим телима вредност робе (Bianchi 2013: 1).

Одлука да протагонисткиња буде проститутка може се приписати управо Валенсуелиној намери да прикаже како је тело жене главна тачка која се напада. Куповина и продаја сексуалних услуга деградира жене и оне бивају подвргнуте суровом, бруталном и нехуманом опхођењу (MacKinnon 1993: 13). Проституција самим тим представља покушај доминације и потчињавање жена, при чему треба истаћи да је доминација мушкарца над женом како физичка, тако и психичка (MacKinnon 1993: 25). Употребом Клариног тела, његовим поседовањем, мушкарци у Кларином животу су заправо контролисали њен живот и слободу. Чак и када није било речи о њеним клијентима, већ партнерима, ситуација је била иста. Заправо, управо се кроз партнерске односе види потреба мушкарца да преко тела утиче на укидање женског гласа, односно њених ставова и мишљења.

Трагичност Клариног живота је у томе што, било да користи тело или главу, нечега мора да се одрекне и нешто јој се ускраћује. Такође, кроз приказ недостатка борбености код протагонисткиње, изводи се закључак о репресивности жене од стране друштва, која кулминира на самом крају романа: „То је моја судбина, после свега. Нема више сврхе да бежим, ни да вичем, ни да се браним“ (Valensuela 2017: 181).

Валенсуела се залаже за то да треба прекинути традицију у оквиру које мушкарци говоре о женским телима и који га откривају. Валенсуелина дела преносе поруку да треба прекинути с приказивањем женског тела као огледала мушке пожуде (Magnarelli 1996: 71). Закључујемо да управо зато Клара истражује значај свог тела, своју пожељност и шта са својим телом жели да ради, како би се побунила против мушкараца који је читав њен живот дефинишу. С друге стране, кроз приказивање објективизације протагонисткиње врши се критика друштва. Основа патријархалног система јесте претпоставка да мушкарац располаже женским телом, док је жена дужна да испуни оно за шта је биолошки предодређена (Vasiljević 2008: 101). Стога, Валенсуела кроз своју протагонисткињу и приказивањем опхођења мушкараца према 
њој жели да укаже на то да жене морају да пронађу своје оруђе борбе и изражавања. Иако се протагонисткиња не бори за себе вербално, њено тело говори за њу, у њему је исписана њена прича.

\section{Закључак}

Луиса Валенсуела одлучује да прикаже лик жене унутар друштвеног контекста излазећи из тадашњих устаљених оквира. Роман Мораш да се смешкаш приказује доминацију мушкарца над женом. Протагонистикиња романа је приказана као жена чија животна трагедија лежи управо у чињеници да не може да побегне од шаблона које је друштво формирало. Друштвено-политичке околности су креирале друштво у оквиру којег се контролисање жене и насиље сматрало очекиваним, подједнако као и њена пасивност. У оквиру романа Мораш да се смешкаш под насиљем подразумевамо пре свега насилну смрт протагонисткиње, као и физичко и психичко потчињавање од стране мушкарца. Од Кларе се очекује да буде предмет мушке пожуде, да задовољава њихове потребе и да им се покори. Сваки вид покушаја да се изађе из предвиђених улога кажњен је од стране друштва. Протагонисткиња је приморана да пребрзо одрасте и да се ослања на мушкарце и своје тело с обзиром на то да није била, по устаљеном обичају, задужена за размишљање, доношење одлука или образовање.

Валенсуела говори о ставу друштва да је добра жена она која испуњава улогу мајке, супруге и домаћице. Међутим, оно што ауторка такође приказује јесте да испуњавање ових улога не представља нужно срећу за сваку жену. Кларини партнери представљени су као доминантни, репресивни, брак представља начин контроле, а не чин љубави. Узрок насиља над женама налази се у друштву које оправдава доминантност мушкараца и везује мужевност за доминацију и моћ. Резултат таквог понашања јесу жене чији је глас одузет, чија се мишљења и ставови виде само кроз мушкарца, када и ако он то дозволи. Борба либералне и конзервативне идеологије која се одвијала у Аргентини представљена је на Кларином примеру.

\footnotetext{
${ }^{1}$ Што се тиче могуће повезаности с Бартовим идејама у Валенсуелиним есејима, интервјуима или радовима, о овом концепту није се наилазило на директно позивање на Барта.

2 Из разговора поводом Сајма књига у Лими, одржаног 2007. године. Види:https://www.youtube.com/watch?app=desktop\&v=ULlvvW2Qej8\&list=LLMl8vCRAcQ49S7Kai7Y6ow\&index=9\&t=7s (приступљено 6. 8. 2021).
} 


\section{Литература}

Bianchi, Paula Daniela. "La subjetividad y el goce femeninos. Las nuevas representaciones de las prostitutas en la literatura latinoamericana contemporánea. Cuerpos, placeres y alteraciones.”. Hispanet Journal 1 (2013): 1-25.

Díaz, Gwendolyn. “El cuerpo como texto político en el cuento de Luisa Valenzuela”. Letras femeninas 27.1 (2001): 164-176.

Favero, Bettina. "Las voces de una juventud silenciosa: memoria y política entre los otros jóvenes durante los años 60 (Mar del Plata-Argentina)”. Historia y MEMORIA 12 (2016): 215-252.

Hatry, Laura. “Género, poder y violencia en la obra de Luisa Valenzuela”. Boletín Millares Carlo 29 (2010): 333-348.

Justo von Lurzer, Carolina. “Sexo, amor y dinero. Representaciones televisivas de la prostitución en Argentina”. Apuntes de investigación del CECYP 23 (2013): 72-110.

Cosse, Isabella. "Cultura y sexualidad en la Argentina de los 60': usos y resignificaciones de la experiencia trasnacional.”. E.I.A.L. 15.1 (2006): 39-60.

Craig, Linda. Juan Carlos Onetti, Manuel Puig and Luisa Valenzuela. vol. 219. United Kingdom: Tamesis Books (2005): 109-130.

Magnarelli, Sharon. "Luisa Valenzuela: Cuerpos que escriben (metonímicamente hablando) y la metáfora peligrosa”. En La palabras en vilo: narrativa de Luisa Valenzuela, editoras Gwendolyn Díaz y María Inés Lagos, 53-79. Santiago de Chile: Editorial Cuarto Propio 1996.

Marković, Ana. La identidad femenina y las relaciones de poder en los relatos de Luisa Valenzuela. Barcelona: Universitat de Barcelona, 2013. 
MacKinnon, Catharine. "Prostitution and civil rights". Mich. J. Gender \& L. 13 (1993): 13-31.

Morcillo, Santiago, Cecilia Varela. "Ninguna mujer...El abolicionismo de la prostitución en la Argentina”. Sexualidad, Salud y Sociedad-Revista Latinoamericana 26 (2017): 213-235.

Pina, Raquel G. "La literatura como espacio de resistencia. Mujer y maternidad: la falacia del espacio privado.” Revista de Crítica Literaria Latinoamericana 32.63/64 (2006): 297-310.

Rohrer, Kristine L. Los temas de poder en las obras de Luisa Valenzuela, Toledo: University of Toledo, 2012.

Romero, Luis Alberto. "La violencia en la historia argentina reciente: un estado de la cuestión”. En Historizar el pasado vivo en América Latina, editora Anne Pérotin-Dumon, 3137. Argentina: Universidad Alberto Hurtado, 2007.

Prigorian, Nelly and Carmen Díaz Orozco. "La Tradición Reformista del Feminismo Latinoamericano”. Representaciones, emergencias y resistencias de la crítica cultura, Buenos Aires: CLASCO, 2017.

Sagot, Montserrat. "Estrategias para enfrentar la violencia contra las mujeres: reflexiones feministas desde América Latina”, Athenea Digital. Revista de pensamiento e investigación social núm. 14 (2008): 215-222.

Valensuela, Luisa. Opasne reči, Novi Sad: Agora, 2019.

Vasiljević, Lidija. „Feminističke kritike: pitanje braka, porodice i roditeljstva“. U Neko je rekao feminizam?, priredila Adriana Zaharijević, 94-118. Beograd: Heinrich Böll Stiftung, 2008. 


\section{Извор}

Valensuela, Luisa. Moraš da se smeškaš. Zrenjanin: Agora, 2017.

\section{Други извори}

Интервју Луисе Валенсуеле поводом одржавања Сајма књига у Лими 2007. године $\quad$ https://www.youtube.com/watch?v=ULlvvW2Qej8\&list=LLMl8vCRAcQ$\underline{49 S 7 K a i 7 Y 6 o w \& i n d e x=9 \& \mathrm{t}=7 \mathrm{~s}}$

6.

8.

2021). 


\section{A Woman's Search for Her Identity in Luisa Valenzuela's Novel You Have To Smile}

This article analyzes the novel You Have to Smile by Luisa Valenzuela, in an attempt to show the birth of feminist ideas not only in the author's works but also in Argentinian literary works. Through the protagonist Clara, the novel critically thematizes the position of women and their search for identity. In this regard, the paper emphasizes the influence of society and the family in the formation of women's identity and position. It also analyzes how the author presents the body of the protagonist as a battleground of old and new ideologies in Argentina in the 1960s. The family and society will create a system within which a woman is subordinate to a man and his decisions. This results in the objectification and dehumanization of the protagonist, through whom Valenzuela represents a whole generation of submissive and silenced women.

Keywords: identity, woman, feminism, Luisa Valenzuela 